\title{
KNOWLEDGE TRANSFER (KT) \\ PRACTICES IN SMALL AND MEDIUM \\ ENTERPRISES (SMEs) of TURKISH \\ TEXTILE AND APPAREL INDUSTRY
}

\author{
*Dababrata Narayan CHOWDHURY \\ *Lynne BUTEL \\ **I. Hakkı ERASLAN \\ ***İsmail BAKAN \\ *University of Plymouth, UK \\ **International Competitiveness Research Institute (URAK), Turkey \\ ***Kahramanmaraş Sütçü İmam University, Turkey
}

\begin{abstract}
This paper examines how knowledge is developed in supplier or buyer relationships in Turkish SMEs. The knowledge transfer activities in Turkish textile and apparel industry have been explored in this study. The knowledge transfer is undisputedly important subjects as knowledge provides competitive advantage to firms. Only few percentages of the Turkish textile and apparel industry are engaged in knowledge transfer activity although it is recorded as the largest industry in Turkish economy. Turkish textile and apparel industry is mostly run by family and most of them are either unaware or reluctant to involve in the knowledge transfer activities. This study examines the knowledge transfer practices in Turkish textile and apparel industry's SMEs through qualitative research and quantitative analysis by undertaking extensive literature reviews and present situation in Turkey.
\end{abstract}

Keywords: knowledge transfer (KT), Turkish textile and apparel industry, SMEs.

\section{INTRODUCTION}

Textile and apparel industry in Turkey has played a vital role in the industrialization process and market orientation of the economy in the last three decades. For many developing countries, the manufacturing sector serves as the main powerhouse in fuelling growth for the economy through the generation of export earnings and employment. The same as, in the early years of liberalization, the Turkish textile and apparel industry posted strong consistent growth in terms of exports. With the drive towards liberalization since the early 1980s, the textile and apparel industry gradually increased and eventually became one of the dominant industry groups in Turkey. During the period between 1980 and 2000, the textile and apparel industry alone recorded an average annual output growth of 20.5 percent and eventually became the country's largest manufacturing export industry in value terms (TGSD, 2008; IGEME, 2008; Eraslan, 2008). However, with the inclusion of China to the global textile and apparel market, the volume of textile and apparel exports of Turkey have started to decline since 2000s (ITKIB, 2006). 
Textile and apparel industry has always had a forefront position in the economy of Turkey. Such activities at the industrial level date back to the early Ottoman period. Since those times, the highest levels of employment, production and profits in the economy of the country were obtained in textiles and related fields (Akalin, 2001; Ercan, 2002). Today, the textile and apparel sector employs 2 million people (the 2nd largest employer after agriculture sector), generates about $1 / 5^{\text {th }}$ of the total export earnings and contributes $11 \%$ to the GDP thereby making it the largest industrial sector of the country (14\% of total manufacturing industry production). The sector aspires to grow its revenue and export value (Eraslan, 2008; ITKIB, 2006).

This paper focuses on the process of knowledge transfer and its determinant factors that clarify its effectiveness for Turkish textile and apparel industry. In summary, the research in this paper is based on the understanding that knowledge transfer in a Turkish textile and apparel industry is critical to an organization's success, and that there is a need for more empirical investigation of knowledge transfer. In this research, an attempt is made to determine the growing importance of knowledge transfer through determinant factors to the development of textile and apparel industry in Turkey.

\section{Understanding Knowledge Transfer (KT)}

Transfer of knowledge from one set of individuals to another has been a key area of interest for knowledge management and knowledge transfer researchers. The terms knowledge transfer (Garvin, 1993; Gupta \& Govindarajan, 2000a, 2000b), knowledge dissemination (Demarest, 1997; McAdam \& McCreedy, 1999), knowledge flows (Gupta \& Govindarajan, 2000b), and knowledge distribution (Huber, 1991) appear to be used interchangeably in the literature to describe the process of knowledge transfer. The literature identifies that knowledge transfer is a dynamic process between the individual or group and the organization's knowledge stocks. Knowledge moves simultaneously forwards and backwards between individuals, groups and the organization to become embedded in the organization's routines, behaviors and strategic orientations (Argyris \& Schon, 1974; Argyris \& Schon, 1978; Grant, 1996; Levitt \& March 1988; March \& Olsen 1975).

Transfer of knowledge includes two actions; one is transmission which means sending knowledge to potential receiver, and another is absorption meaning that knowledge must be incorporated either by a person or a group. As such, Davenport and Prusak have expressed this concept as Transfer = Transmission + Absorption (Davenport \& Prusak, 1998). The availability of knowledge is not sufficient; it should also ensure the usability of available knowledge. Knowledge that isn't absorbed hasn't really been transferred (Ibid). Davenport and Prusak further argues that transmission and absorption has no meaning if new knowledge does not lead to some change in behavior. Bajracharya and Masdeu (2006) argue that considering this notion, it appears that transferring knowledge is rather very smooth process. Therefore, while knowledge transfer between firms includes the flow of knowledge between SMEs and the ability to understand and to utilize this knowledge, it also includes the reality that the evidence of knowledge transfer may not always be easy to observe because tacit knowledge is not as tangible; therefore when considering knowledge transfer we need to consider the character of knowledge.

\section{The Process of Knowledge Creation and Transfer}

According to Argote and Ingram (2000) knowledge transfer in organizations is the process where one unit, e.g. group, department, or division learns by the experience of another. They recognized that knowledge can be transferred in two ways, either by moving a knowledge pool, people or tech- 
nology, from one unit to another, or by modifying a knowledge pool. People and technology can thus be moved between units and modification can be achieved through communication and training. Tacit knowledge can be transferred to other tasks and contexts by moving people whereas transferring knowledge by embedding it in technology are only effective if accompanied by a few individuals because the individuals have the tacit knowledge and understanding behind the technology. The models based on Nonaka and Takeuchi's (1995) conventional theory of knowledge creation and the concept of intellectual capital (Stewart, 1997; 2001) provide an insight on the role of knowledge transfer in knowledge creation and explained next.

Nonaka and Takeuchi (1995) defined four independent modes for knowledge creation; (1) socialization, from tacit knowledge to tacit knowledge, (2) externalization, from tacit knowledge to explicit knowledge, (3) combination, from explicit knowledge to explicit knowledge, and (4) internalization, from explicit knowledge to tacit knowledge. Most knowledge is nevertheless created with the combination of the different modes. According to Nonaka and Takeuchi (1995) organizational knowledge is formed where knowledge is initially created by the individuals in the organization. Tacit knowledge becomes explicit and then transferred from individuals to groups and in the end to the organization. This creates a positive knowledge spiral (Nonaka \& Takeuchi, 1995) which can start from any of the four modes but usually begins with socialization. Polanyi's (1967) contradicted the above view because tacit knowledge cannot by definition be made explicit and knowledge transfer in a spiral mode cannot be thus accomplished. Figure 1.1 shows the knowledge transfer in spiral mode as indicated by Nonaka and Takeuchi (1995). The four modes used in knowledge transfer are now explained next.

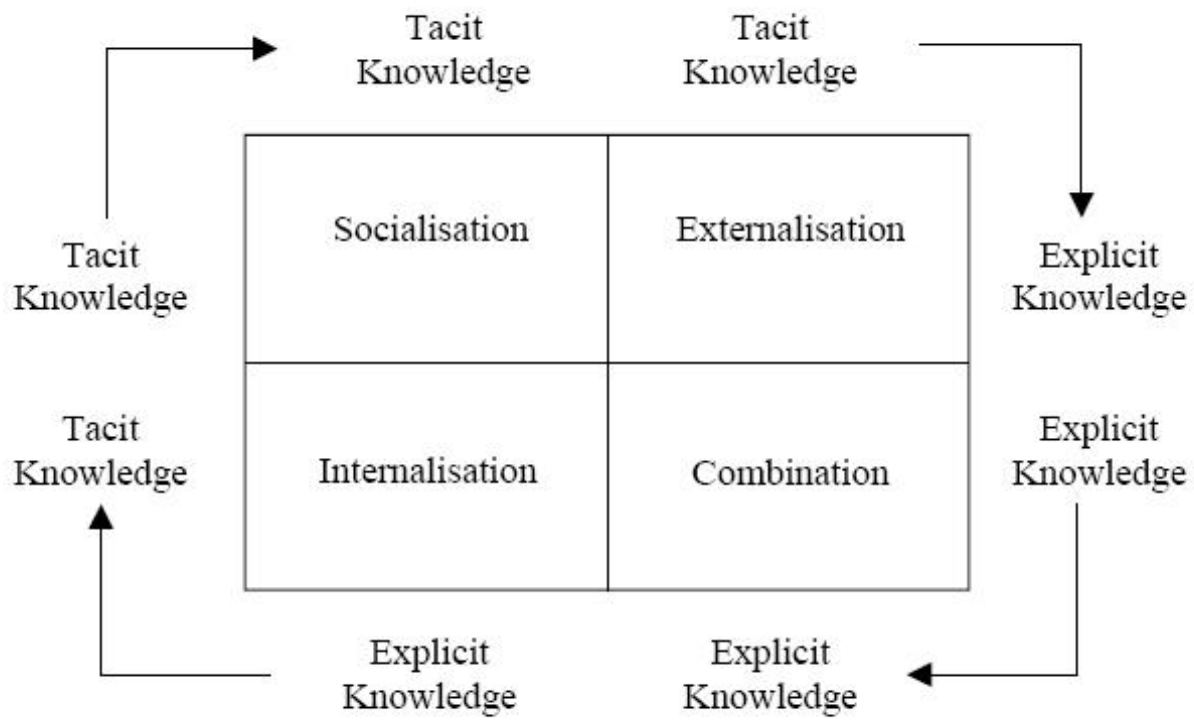

\section{Figure 1.1: Four modes of Knowledge Creation and Transfer (Nonaka\& Ta- keuchi, 1995)}

\section{HYPOTHESES}

The SMEs in Turkish textile and apparel industry, especially the larger ones and those with specialized knowledge and technology, do have clear growth strategies and generally have no problems complying with regulations, quality systems and staff development or in sharing their views with 
other network members or more widely (TGSD, 2008). Feedbacks obtained from face to face interviews indicated that most Turkish SMEs, even those that are active in several networks, do not have the inclination, knowledge or resource to comply. Lack of knowledge management, lack of interest and support from government and non-government organizations also hampers the progress of SMEs. More or less every Turkish SMEs covered in this interview indicated the growing need of IT for knowledge transfer within and between SMEs. Most of the SMEs lack knowledge sharing and importance of the trust on which the knowledge transfer can be effectively built. They also understood the importance of various IT components and expertise acting as a communication channel and their necessity for effective knowledge transfer. The next sections thus identify various factors under different themes on the basis of the available literature. To test the relevance of various themes for Turkish SMEs, two different hypotheses with eight sub-hypotheses are developed and will be further analyzed in coming section.

\section{$\mathrm{H}_{1}$ : Knowledge Sharing for KT}

According to Nonaka and Takeuchi (1995) knowledge conception is considered like a growth process started by the individual and then moves across the organization in a never-ending process. Davenport and Prusak (2000) suggested that knowledge transfer process involves two actions: transmission of knowledge to potential recipient, and absorption of the knowledge by that recipient that could eventually lead to changes in behavior or the development of new knowledge.

The key aspects of knowledge transfer are thus transmission of some knowledge to the recipient leading to creation of new knowledge or changes in behavior. In the economic environment, firms must have the appropriate knowledge and use it efficiently. Because of geographical size and dispersion the transfer of existing organizational knowledge to other places knowing where it is actually needed becomes difficult (Davenport and Prusak, 1998). Boisot (1998) argues that successful knowledge transfer needs a degree of resonance between two or more agents. Knowledge transfer thus requires both the transfer or sending of knowledge from the source agent and the internalization or learning of that knowledge by the recipient agent. This transfer of knowledge depends on the type and complexity of the knowledge and is also affected by the attributes and behaviors of the human agents sharing that knowledge.

It is important to distinguish knowledge sharing at different levels: individual, group and organization. Huber (1991) indicated that knowledge sharing between individuals may not always be easily seen as some knowledge transfer. It can alter a person's awareness but not their behavior. Knowledge sharing helps to obtain more complete knowledge and information to take better informed decisions (Gynawali, Stewert \& Grant, 1997). Face to face interviews from persons at higher position in Turkish textile and apparel industry also indicated that 12 out of 18 considered the importance of sharing business ideas and information with buyers and 15 out of 18 with suppliers and that helps in knowledge transfer activities.

These determinants affecting the knowledge sharing will form the basis of hypothesis to study the impact of knowledge transfer in Turkish textile and apparel SMEs:

$H_{1}:$ Turkish SMEs share knowledge within their network

$\mathrm{H}_{1 \mathrm{a}}$ : From buyer's ideas

$\mathrm{H}_{1 \mathrm{~b}}$ : From supplier's ideas

$\mathrm{H}_{2}$ : Implementation of IT technology 
Huysman \& DeWit (2002) have noted that many knowledge management projects had their origin in the information technology (IT) world. Organizations believe that with the rise of advanced technology, opportunities to facilitate knowledge transfer and sharing with organizations are on the increase. Frappaolo \& Capshaw (1999) noted that the key applications of KM projects are effectively connecting knowledge throughout the organization among different entities. The focus is on ensuring that each individual or group understands the knowledge available with sufficient depth as to be applied effectively in decision-making and improvement. IT had played a vital role in providing the infrastructure needed to support knowledge transfer and sharing within and between organizations. The media and channels of communication are one of the sources for the creation, storage and transfer of knowledge. Swan et al. (1999) conducted a study comparing two cases. One of them focused almost entirely on using IT (intranet) for knowledge transfer without considering any social factors. In the other, IT was used to provide a network to encourage sharing together with the recognition of the importance of face-to-face interaction for sharing knowledge. The emphasis was on encouraging active network among dispersed communities. According to this study it was observed that knowledge cannot be simply processed and it must be continuously re-created through dynamic, interactive social networking activity. Nonaka \& Takeuchi (1995) also believed that IT enables data processing on a large scale, crossing the boundaries of time and space but should have social factor. Any technology-driven intervention aimed at supporting knowledge sharing therefore needs to be aligned with the social and organizational mechanisms of knowledge transfer.

Internet and E-mail system are convenient tools to broadcast top management's messages to whole organization. Top management of an organization can send all at once a message in the text or video formats to every member of the organization using internet based broadcasting system (Nonaka, 1991). Yang (2003) also supported that these will help in reducing geographical barriers. Communication media such as E-mail, a Video Conferencing System, Internal Electronics Bulletin Board can thus be used for the quick transfer of new knowledge. The Internet, the World Wide Web, and other ongoing advancements in information technology (IT) are supporting the efforts to create, integrate, and transfer information and knowledge among SMEs networks (Stover, 2004). Face to face interview conducted also supported the use of IT resources and mostly indicated the application of Email (15/18), Internet (17/18), Company website (10/18), E-library (9/18), Internet electronic bulletin board (10/18) and Video conferencing (8/18) are useful for KT.

The below hypothesis in the context of Turkish SMEs study the effect of implementation of IT through many channels on knowledge transfer:

$\mathrm{H}_{2}$ : Adoption and utilization of the IT applications in the Turkish SMEs is essential for their success:

$\mathrm{H}_{2 \mathrm{a}}$ : by Company's website

$\mathrm{H}_{2 \mathrm{~b}}$ : by E-mail

$\mathrm{H}_{2 \mathrm{c}}$ : by Video Conferencing

$\mathrm{H}_{2 \mathrm{~d}}$ : by E-library

$\mathrm{H}_{2 \mathrm{e}}$ : by Internet

$\mathrm{H}_{2 \mathrm{f}}$ : by Internal Electronics Bulletin Board

\section{RESEARCH METHODOLOGY}

The object of this section is to explain and discuss the methodology to propose the suitable types that match this study best. Firstly, semi-structured interviews were used to collect data for qualitative 
analysis. Secondly, a questionnaire was used to collect data for quantitative analysis. Both data was collected from Turkish textile and apparel industry at two different times to increase the reliability of the findings. This multi-method approach provided both a broader and complementary approach. The research intended to develop an understanding of knowledge transfer in a small number of SMEs, and then to explore this understanding in a large number of SMEs for quantitative analysis. The interview was first designed to gather qualitative information and then the questionnaire was used to collect data for quantitative analysis that built on the results from the analysis of the qualitative finding. The research then required further explanation of existing information moving into a positivistic paradigm. First, it was required to confirm the qualitative findings and increase the reliability of the results then investigate quantitative findings to improve the validity of the analysis and investigate knowledge transfer in better strength.

\section{Hypotheses Test and Results}

This section tests the correlation and ANOVA test between two independent variables with knowledge transfer. The variables are ideas from buyers and suppliers and analysis is to test the relationship of these with KT.

Table 1.1: Correlation between Variables and Knowledge Transfer

\begin{tabular}{|l|c|c|c|c|}
\hline & & Knowledge Transfer & Share Ideas with Buyers & $\begin{array}{c}\text { Share Ideas with } \\
\text { Suppliers }\end{array}$ \\
\hline Knowledge transfer & Pearson Correlation & 1,000 & & \\
\hline Share ideas with buyers & Pearson Correlation &,- 044 & 1,000 & \\
\hline Share ideas with suppliers & Pearson Correlation &,- 026 &, $864(* *)$ & 1,000 \\
\hline
\end{tabular}

** Correlation is significant at the 0.01 level (2-tailed).

The results in Table 1.1 indicates that there is a negative correlation between the sharing ideas with buyers [ $\mathrm{r}=-0.044, \mathrm{~N}=264, \mathrm{p}>0.05]$ and sharing ideas with suppliers $[\mathrm{r}=-0.026, \mathrm{~N}=265, \mathrm{p}>0.05]$ with knowledge transfer, indicating that there is no significant relationship between sharing ideas with buyers and sharing ideas with suppliers with knowledge transfer.

\section{Table 1.2: ANOVA Test for Hypothesis 1}

\begin{tabular}{|l|r|c|c|c|c|c|}
\hline & & Sum of Squares & df & Mean Square & F & Sig. \\
\hline \multirow{4}{*}{$\begin{array}{l}\text { Share Ideas with } \\
\text { Buyers }\end{array}$} & Between Groups & $4,19 \mathrm{E}-02$ & 3 & $1,40 \mathrm{E}-02$ & 0,932 & 0,426 \\
\cline { 2 - 7 } & Within Groups & 3,897 & 260 & $1,50 \mathrm{E}-02$ & $<2.63$ & \\
\cline { 2 - 7 } & Total & 3,939 & 263 & & & \\
\hline \multirow{4}{*}{$\begin{array}{l}\text { Share Ideas with } \\
\text { Suppliers }\end{array}$} & Between Groups & $5,76 \mathrm{E}-02$ & 3 & $1,92 \mathrm{E}-02$ & 1,723 & 0,163 \\
\cline { 2 - 7 } & Within Groups & 2,908 & 261 & $1,11 \mathrm{E}-02$ & $<2.63$ & \\
\cline { 2 - 7 } & Total & 2,966 & 264 & & & \\
\hline
\end{tabular}

To understand this relationship in detail and see the effects of each level, one-way ANOVA test is conducted next. The data collected here studies the effect of multiple level of one factor with multiple observations at each level. Multiple t-tests are not the answer because there are a large number of groups. With this kind of layout a calculation of the mean of each level is required to observe the variation within each level. The comparison between the actual variations of the group averages with 
expected variation indicates the level effect present in the data. More detail of the level effects can be obtained by studying the deviation of the mean of each level from grand mean. The one-way ANOVA is useful to compare the effects of multiple levels with multiple observations at each level and utilized here to study the behavior of different variables on knowledge transfer. ANOVA puts all the data into one number $(F)$ and provides one $P$ for the null hypothesis. The ANOVA test compare to other comparison tests such as t- tests also has fewer experiment- wise error rates (http:// www.psychstat.missouristat.edu), and considered appropriate here to test the hypothesis. Table 1.2 shows the ANOVA tests for hypothesis $\mathrm{H}_{1}$ to consider the effect of two sub-hypotheses $\mathrm{H}_{1 \mathrm{a}}$ and $\mathrm{H}_{1 b}$ on knowledge transfer. The relationship of each sub-hypothesis on knowledge transfer in Turkish SMEs is considered next.

$H_{1 a}:$ Turkish SMEs share knowledge within their network from buyer's ideas

The Table 1.2 shows the value of $\mathrm{F}=0.932$ which is smaller than the critical value of 2.63 for the $\mathrm{F}$ distribution at 3 and 260 degrees of freedom and $95 \%$ of confidence (obtained using online calculator for critical value of $F$ from http://www.danielsoper.com). The significant value $\mathrm{p}>0.05$ indicates that effects are not significant. There is sufficient evidence to accept the null hypothesis and thus alternative hypothesis $\mathrm{H}_{1 \mathrm{a}}$ is rejected.

$H_{l b}$ : Turkish SMEs share knowledge within their network from supplier's ideas

The Table 1.2 shows the value of $\mathrm{F}=1.723$ which is smaller than the critical value of 2.63 for the $\mathrm{F}$ distribution at 3 and 261 degrees of freedom and $95 \%$ of confidence. The significant value of $p>0.05$ with value of $\mathrm{F}$ indicates that the null hypothesis is accepted and thus alternative hypothesis $\mathrm{H}_{1 \mathrm{~b}}$ is rejected. This concludes that knowledge transfer is not directly affected with the sharing of knowledge from buyers and suppliers. The trend in means as shown in Graphs 1.1 and 1.2 also confirmed that there is weak form of relationship with knowledge transfer.

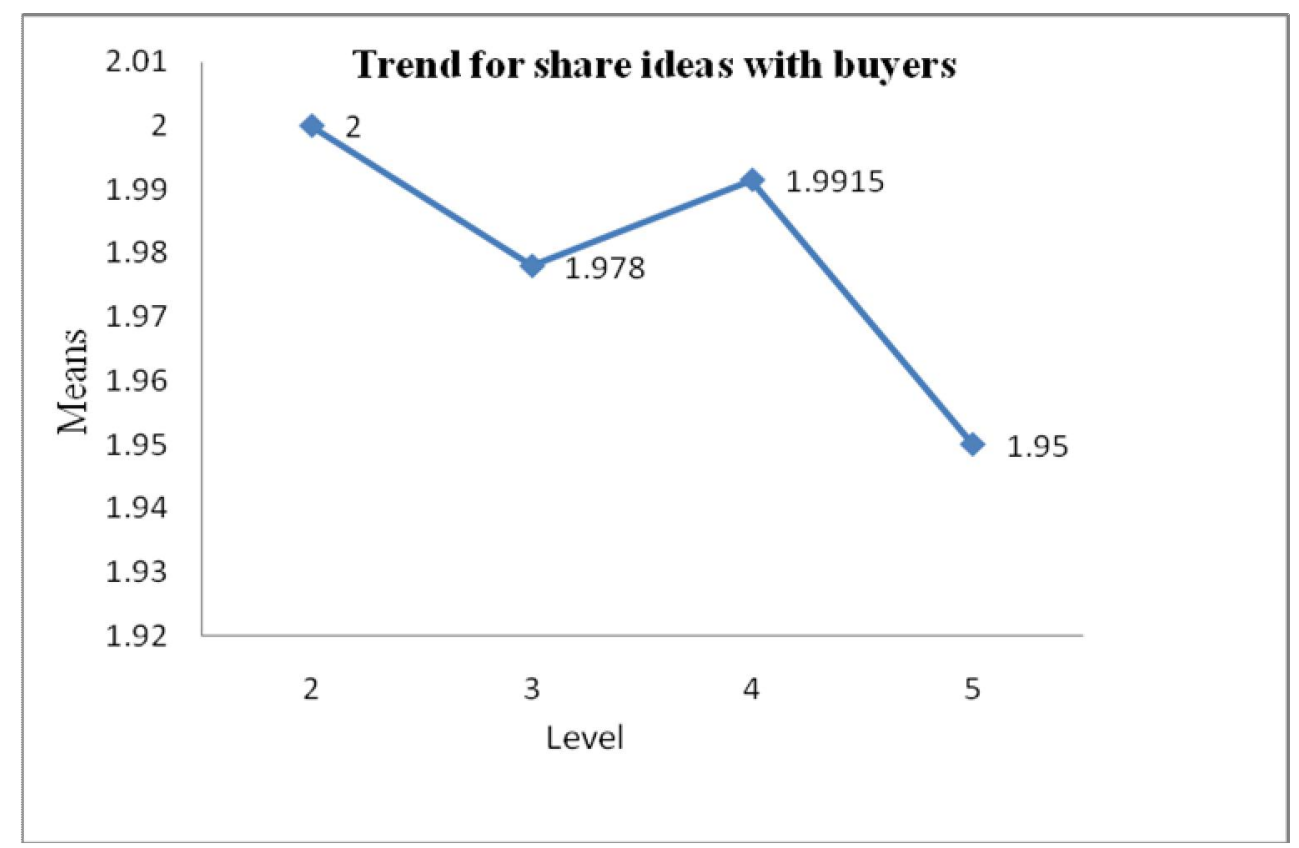

\section{Graph 1.1: Trend for Share Ideas with Buyers for KT}




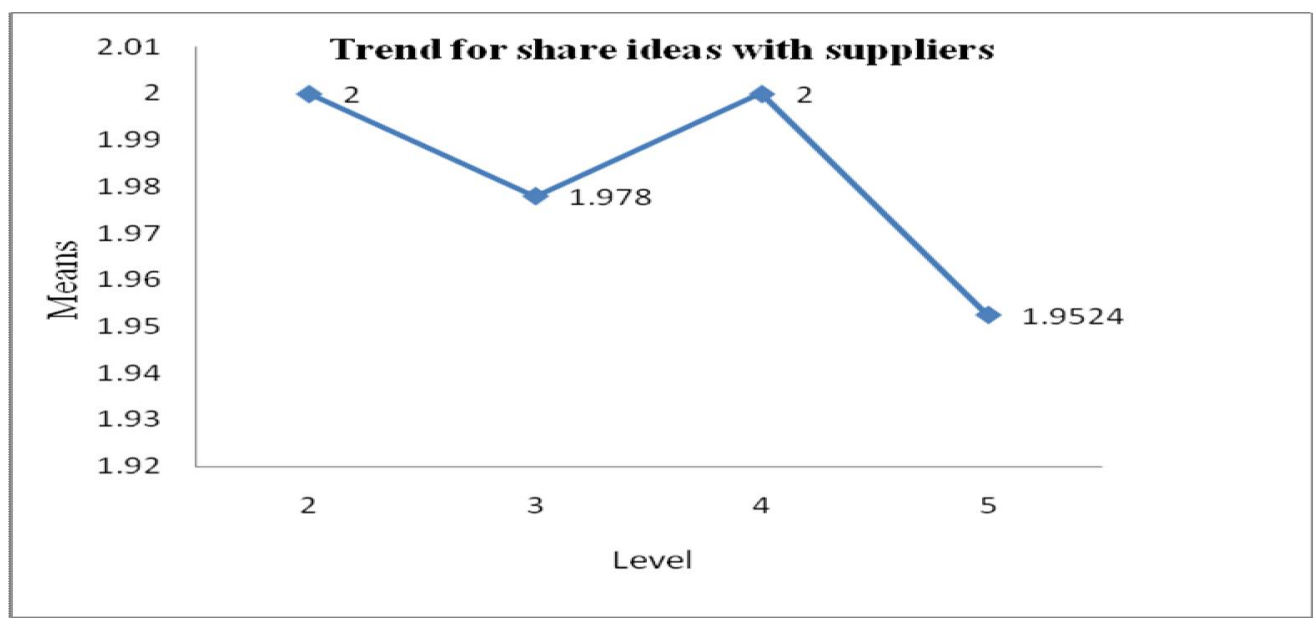

Graph 1.2: Trend for Share Ideas with Suppliers for KT

Table 1.3: Summary of the Results of the Testing of Hypothesis 1

\begin{tabular}{|l|l|}
\hline$H_{1 a}$-From buyer's ideas & Not Supported \\
\hline$H_{1 b}$-From supplier's ideas & Not Supported \\
\hline
\end{tabular}

Finding for Hypothesis 1: The above two sub-hypotheses are not supported by the respondents and overall $\mathrm{H}_{1}$ is thus rejected.

The following analysis will test the correlation between two variables from Turkish SMEs employees considering various factors supporting the hypotheses: $\mathrm{H}_{2}$ : Adoption and utilization of the IT applications in the Turkish SMEs is essential for their success. The correlation coefficients will be first conducted to test the supporting relation between these two variables for the same factor. For example in case of a Company's website, how useful this factor is for adoption and utilization of IT in the organization. This correlation coefficient will thus indicate the support of each factor in the adoption and utilization of IT technology.

The Table 1.4 shows the correlation coefficients and significance levels for each factor. There is a strong positive correlation between the two variables for Company's website $[\mathrm{r}=0.815, \mathrm{~N}=260$, $\mathrm{p}<0.01]$, indicating that Company's website is important. Similarly there is strong positive relationship for E-mail $[r=0.825, \mathrm{~N}=265, \mathrm{p}<0.01]$, Internet $[\mathrm{r}=0.405, \mathrm{~N}=265, \mathrm{p}<0,01]$ and Internet Electronic Bulletin Board [ $\mathrm{r}=0.437, \mathrm{~N}=265, \mathrm{p}<0.01]$. Only two factors show weak relationship but both are positive with high statistical significant. The value for Video conferencing is $[\mathrm{r}=0.132, \mathrm{~N}=265$, $\mathrm{p}<0.05]$ whereas for E-library is $[\mathrm{r}=0.242, \mathrm{~N}=265, \mathrm{p}<0.01]$. The comparatively low value is may be due to the unawareness of these two new technologies in Turkey for KT. 
Table 1.4: Correlation Test for Hypothesis $2\left(\mathbf{H}_{2}\right)$

\begin{tabular}{|c|c|c|c|c|c|c|c|c|c|c|c|c|}
\hline \multicolumn{13}{|c|}{ Crreations } \\
\hline & $\begin{array}{c}\text { TMos. usefu } \\
\text { ter ldea } \\
\text { shating. } \\
\text { Companys } \\
\text { nebsies } \\
\end{array}$ & $\begin{array}{c}\text { TMss useful } \\
\text { for dea } \\
\text { haring-Em aily }\end{array}$ & $\mid \begin{array}{c}\text { Most Lseful } \\
\text { forldsa } \\
\text { harng-Videó } \\
\text { con'elencing }\end{array}$ & $\begin{array}{c}\text { Tost usefulf } \\
\text { frrldea } \\
\text { sharing-E- } \\
\text { Library }\end{array}$ & $\begin{array}{l}\text { Most useful } \\
\text { torlded } \\
\text { sharing. } \\
\text { Internat }\end{array}$ & $\begin{array}{l}\text { T Most useful| } \\
\text { 'orlced } \\
\text { sharinç- } \\
\text { ntenal } \\
\text { Elestoric } \\
\text { sul etin Bzard }\end{array}$ & $\begin{array}{l}\text { ouj çood IT } \\
\text { pplications } \\
\text { used by } \\
\text { mplyyeess } \\
\text { ompanys } \\
\text { website }\end{array}$ & $\begin{array}{c}\text { 15or good }- \\
\text { applications } \\
\text { Lsed by } \\
\text { employees } \\
\text { Email }\end{array}$ & $\begin{array}{c}\text { how good IT } \\
\text { apslications } \\
\text { used by } \\
\text { smployess } \\
\text { V deo } \\
\text { Eonferencing }\end{array}$ & $\begin{array}{c}\text { ow gosd IT } \\
\text { sppl catisrs } \\
\text { Jsed by } \\
\text { enployees } \\
\text { E-libary }\end{array}$ & 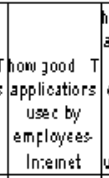 & $\begin{array}{l}\text { hoongcod T } \\
\text { applicatiors } \\
\text { used ty } \\
\text { empleyees } \\
\text { Intenal } \\
\text { Electonic } \\
\text { ul etin baard }\end{array}$ \\
\hline \multirow{3}{*}{ 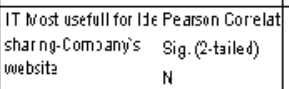 } & 1 & $815^{\circ}$ & .13 & .097 & $584^{\circ}$ & $.611^{x^{x}}$ & $85^{\prime \prime}$ & 6: $1=$ & $.447^{\prime \prime}$ & $.447^{x^{x}}$ & $.409^{x}$ & $.281^{x}$ \\
\hline & & .00 & 070 & 10 & 000 & .00 & 000 & 000 & 000 & .00 & $\infty$ & 000 \\
\hline & 263 & 260 & 260 & 260 & 260 & $23 \mathrm{C}$ & 260 & 260 & 260 & $23 \mathrm{C}$ & 260 & 260 \\
\hline \multirow{3}{*}{$\begin{array}{ll}\text { IT Nost usefull for } I f \in \text { Pearson Corelat } \\
\text { shar ng-Emal } & \text { Sig. (2.tailed) } \\
& N\end{array}$} & $815^{x}$ & 1 & .10 & .094 & $738^{\circ}$ & $.71^{2 x}$ & $1000^{\circ}$ & $825=$ & $.558^{\prime \prime}$ & $-55 \xi^{*}$ & $.500^{\circ}$ & $340^{\circ \prime}$ \\
\hline & .003 & & 073 & 127 & 000 & $.0 \mathrm{xc}$ & 000 & 000 & 000 & $.00 \mathrm{C}$ & .000 & .000 \\
\hline & 265 & 205 & 265 & 265 & 265 & $28 E$ & 265 & 265 & 265 & $25 E$ & 265 & 265 \\
\hline \multirow{3}{*}{$\begin{array}{ll}\text { IT Most usefull for Ife Pearson Corelat } \\
\text { shar ng-Vide) } & \text { Sig. (2-tailed) } \\
\text { ecnferencing } & \text { N }\end{array}$} & .113 & .110 & 1 & \begin{tabular}{|c|}
.088 \\
\end{tabular} & 036 & $.03^{E}$ & . & 053 & $132^{\circ}$ & $.132^{x}$ & .045 & .076 \\
\hline & .073 & .073 & & 154 & 565 & .296 & 073 & 392 & 031 & .031 & .482 & .215 \\
\hline & 28] & & 285 & 285 & 285 & $23 E$ & 286 & 285 & 285 & $23 E$ & 285 & 285 \\
\hline \multirow{3}{*}{$\begin{array}{ll}\text { IT Nost usefull for If Pearson Corelat } \\
\text { shar ng. E-Litrany } \\
\\
\text { Sig.(2-tailed) } \\
\text { N }\end{array}$} & $\begin{array}{l}.097 \\
\end{array}$ & .094 & $\begin{array}{ll}.088 \\
\end{array}$ & 1 & 120 & $.22 \mathrm{~s}^{\mathrm{x}^{2}}$ & .094 & $\begin{array}{l}.010 \\
\end{array}$ & $242^{2}$ & $.244^{x^{x}}$ & .096 & $\therefore 40^{x}$ \\
\hline & .113 & .127 & .154 & & 052 & .000 & .127 & $8: 1$ & 000 & $.0 x 6$ & .120 & .022 \\
\hline & $26]$ & 206 & 265 & 265 & 265 & $23^{E}$ & 265 & 265 & 265 & $23 E$ & 265 & 265 \\
\hline \multirow{3}{*}{\begin{tabular}{ll|}
$\begin{array}{l}\text { IT Nost usefull for lye Pe arson Corelat } \\
\text { shar ng- Inzeinat }\end{array}$ & Sig. (2.tailed) \\
& $N$ \\
\end{tabular}} & $584^{x}$ & ${ }^{\top \Re^{x}}$ & 038 & 120 & 1 & $527^{x}$ & $.739=$ & $811=$ & $.436^{\circ}$ & $.43 \mathrm{E}^{\mathrm{x}}$ & $.405^{x}$ & $.399^{\circ}$ \\
\hline & .003 & .000 & 565 & 052 & & $.0 x$ & 000 & 000 & 000 & $.0 x$ & .000 & .000 \\
\hline & 263 & 265 & 285 & 285 & 285 & 235 & 285 & 285 & 285 & $23 E$ & 285 & 285 \\
\hline \multirow{3}{*}{$\begin{array}{l}\text { IT Nost usefull for If Pe arson Corelat } \\
\text { shar ng. In:enal Sig. (2-tailed) } \\
\text { Electron o Bulletin }{ }^{3}(\mathrm{~N}\end{array}$} & $.611^{x}$ & $.714^{\circ}$ & 065 & $.229^{\circ}$ & $527^{\circ}$ & 1 & $7 \cdot 4:=$ & $654^{*}$ & $.381^{\circ}$ & $.331^{x}$ & $42^{* x}$ & $.43^{7 \times}$ \\
\hline & 003 & .000 & 290 & 000 & 000 & & 000 & 000 & 000 & $.0 x$ & .00 & .000 \\
\hline & $26]$ & 260 & 265 & 265 & 265 & $23 E$ & 265 & 265 & 265 & $23 E$ & 265 & 265 \\
\hline \multirow{3}{*}{ 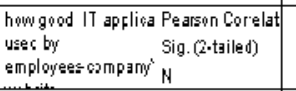 } & $815^{x}$ & $1.00^{\circ}$ & . & .094 & $738^{\circ}$ & $.71^{2^{x}}$ & 1 & $825^{5}$ & $-558^{0}$ & $-55 \xi^{x}$ & $500^{x^{x}}$ & $.340^{x}$ \\
\hline & .003 & .000 & 0,3 & 127 & 000 & $.0 x c$ & & 000 & 000 & $.0 x c$ & .00 & .000 \\
\hline & 26] & 265 & 285 & 285 & 265 & $23 E$ & 286 & 285 & 285 & $23 E$ & 285 & 285 \\
\hline \multirow{3}{*}{$\begin{array}{l}\text { how good IT applica Pearson Corelat } \\
\text { usec by emplorease } \mathrm{Sig} \text { (2-tailed) } \\
\text { N }\end{array}$} & $.671^{x}$ & $.825^{\circ}$ & 053 & $\begin{array}{l}.0 \\
\end{array}$ & $611^{\circ}$ & $.65<^{x}$ & $825=$ & 1 & $-405^{\circ}$ & $-4] e^{x^{x}}$ & $.444^{x}$ & $.292^{\prime \prime}$ \\
\hline & .000 & .000 & 382 & $8: 1$ & 000 & cox & 000 & & 000 & .000 & .00 & .000 \\
\hline & $26]$ & 260 & 265 & 265 & 265 & $23 \mathrm{E}$ & 265 & 265 & 265 & $23 \mathrm{E}$ & 2605 & 265 \\
\hline \multirow{3}{*}{$\begin{array}{l}\text { how good IT applica Pearson Corelat } \\
\text { uses by amployeas V Sig. (2.tailed) } \\
\text { Con'elencing }\end{array}$} & $-.447 \pi$ & $.550^{\circ}$ & $.132^{\prime}$ & $242^{\circ}$ & $.436^{\circ}$ & $.331^{* 2}$ & $-556^{\circ}$ & $.405^{\prime \prime}$ & 1 & $1.000 \times$ & $.18 x^{*}=$ & $-321^{\prime \prime}$ \\
\hline & .003 & .000 & 031 & 000 & 000 & $.0 x$ & 000 & 000 & & $.0 x$ & .003 & .000 \\
\hline & 263 & 265 & 265 & 265 & 265 & $25 E$ & 265 & 265 & 265 & $25 E$ & 265 & $\hat{2}_{65}$ \\
\hline \multirow{3}{*}{$\begin{array}{l}\text { how good IT applies } \\
\text { usec by smployess } \\
\text { E-litrary }\end{array}$} & $-447^{x}$ & $.558^{\circ}$ & $.132^{\prime}$ & $242^{=5}$ & $.436^{\circ}$ & $.331^{x=1}$ & $-558^{*}$ & $.405^{=1}$ & $1000^{\circ}$ & 1 & $.182^{2 x}$ & $-.321^{\prime \prime}$ \\
\hline & .003 & .000 & 031 & 000 & 000 & $.0 x$ & 000 & 000 & 000 & & .003 & .000 \\
\hline & 263 & 266 & 265 & 265 & 265 & $23 E$ & 265 & 265 & 265 & $23 E$ & 265 & 265 \\
\hline \multirow{3}{*}{\begin{tabular}{ll|} 
how good IT ap flica Pearson Corelat \\
uses by & Sig. (2-tailed) \\
employees.nternet & $\mathrm{N}$ \\
\end{tabular}} & $403^{x}$ & $.500^{\circ}$ & .045 & \begin{tabular}{c|}
.096 \\
\end{tabular} & $405^{\circ}$ & $.421^{x}$ & $500=$ & $4: 4: 4$ & $-182^{\circ}$ & $-132^{x}$ & & $.255^{7 \times}$ \\
\hline & .003 & .000 & .462 & 120 & 000 & $.0 x$ & 000 & 000 & 003 & $.00 \pi$ & & .000 \\
\hline & 26] & 265 & 265 & 265 & 265 & $23 E$ & 265 & 265 & 265 & $23 E$ & 2605 & 265 \\
\hline \multirow{3}{*}{$\begin{array}{ll}\text { how good IT apfliea Pearson Corelat } \\
\text { usec by } & \text { Sig.(2-tailed) } \\
\text { employeesinternal } & \mathrm{N}\end{array}$} & $.281^{\pi}$ & $.340^{\mathrm{m}}$ & 078 & $-140^{\circ}$ & $399^{\circ}$ & $.437^{x}$ & $340=$ & $292^{\prime \prime}$ & $.321^{15}$ & $.321^{x=1}$ & $257^{-\pi}$ & 1 \\
\hline & .000 & .000 & $2^{\prime} 5$ & 022 & 000 & $.0 x$ & 000 & 000 & 000 & $.0 x$ & .000 & \\
\hline & 283 & 268 & 285 & 285 & 285 & $23 E$ & 285 & 285 & 285 & $23 \mathrm{E}$ & 285 & 285 \\
\hline
\end{tabular}

". Correlatior is s gnifican: at the 0.01 level (z-tailec)

*. Correlation is sizgnificant at the 0 .Je level (2.tailedi.

The data collected suits for the Chi-square test and it is now performed to explore the relationship between two categorized variables to test the Null hypothesis.

Company's Website $\left(\mathrm{H}_{2 \mathrm{a}}\right)$

Chi-Square Tests

\begin{tabular}{|c|c|c|c|}
\hline & Value & df & $\begin{array}{l}\text { Asymp. } \\
\text { Sig. } \\
\text { (2-sided) }\end{array}$ \\
\hline Pearson Chi-Square & $715,828^{a}$ & $\overline{12}$ &, 000 \\
\hline Likelihood Ratio & 597,239 & 12 &, 000 \\
\hline $\begin{array}{l}\text { Linear-by-Linear } \\
\text { Association }\end{array}$ & 172,174 & 1 &, 000 \\
\hline $\mathrm{N}$ of Valid Cases & 260 & & \\
\hline
\end{tabular}

a. 3 cells $(15,0 \%)$ have expected count less than 5 . The minimum expected count is 2,05 . 
The Pearson Chi-square value for Company's website as shown in above table is with 12 degree of freedom $=715,828$ and significance value $\mathrm{p}<0.05$. These results indicate that there is statistically significant relationship between the variables and thus Null hypothesis $\mathrm{H}_{2 \mathrm{a}}$ is rejected. This implies that alternative hypothesis $\mathrm{H}_{5 \mathrm{a}}$ is supported. However, the Chi-square test does not indicate the extent of relationship between two variables.

E-mail $\left(\mathrm{H}_{2 b}\right)$

Chi-Square Tests

\begin{tabular}{|c|c|c|c|}
\hline & Value & df & $\begin{array}{l}\text { Asymp. } \\
\text { Sig. } \\
\text { (2-sided) }\end{array}$ \\
\hline Pearson Chi-Square & $658,974^{\mathrm{a}}$ & 9 &, 000 \\
\hline Likelihood Ratio & 567,427 & 9 & ,000 \\
\hline $\begin{array}{l}\text { Linear-by-Linear } \\
\text { Association }\end{array}$ & 179,816 & 1 & ,000 \\
\hline $\mathrm{N}$ of Valid Cases & 265 & & \\
\hline
\end{tabular}

a. 0 cells $(, 0 \%)$ have expected count less than 5 . The minimum expected count is 6,66 .

These results indicate there is statistically significant relationship between the variables for E-mail (chi-square with 9 degree of freedom $=658,974, p<0.05$ ) and thus Null hypothesis $\mathrm{H}_{05 \mathrm{~b}}$ is rejected implying that alternative hypothesis $\mathrm{H}_{2 \mathrm{~b}}$ is supported.

Video conferencing $\left(\mathrm{H}_{2 \mathrm{c}}\right)$

Chi-Square Tests

\begin{tabular}{|c|c|c|c|}
\hline & Value & df & $\begin{array}{c}\text { Asymp. } \\
\text { Sig. } \\
\text { (2-sided) }\end{array}$ \\
\hline Pearson Chi-Square & $109,428^{a}$ & 9 & ,000 \\
\hline Likelihood Ratio & 59,330 & 9 &, 000 \\
\hline $\begin{array}{l}\text { Linear-by-Linear } \\
\text { Association }\end{array}$ & 4,625 & 1 & ,032 \\
\hline $\mathrm{N}$ of Valid Cases & 265 & & \\
\hline
\end{tabular}

a. 8 cells $(50,0 \%)$ have expected count less than 5 . The minimum expected count is, 14 .

These results indicate that there is statistically significant relationship between the variables for Video conferencing (chi-square with 9 degree of freedom $=109,428, \mathrm{p}<0.05$ ) and thus Null hypothesis $\mathrm{H}_{05 \mathrm{c}}$ is rejected implying that alternative hypothesis $\mathrm{H}_{2 \mathrm{c}}$ is supported.

E-library $\left(\mathrm{H}_{2 \mathrm{~d}}\right)$

\begin{tabular}{|c|c|c|c|}
\hline \multicolumn{4}{|c|}{ Chi-Square Tests } \\
\hline & Value & $\mathrm{df}$ & $\begin{array}{l}\text { Asymp. } \\
\text { Sig. } \\
\text { (2-sided) }\end{array}$ \\
\hline Pearson Chi-Square & $436,276^{a}$ & 12 &, 000 \\
\hline Likelihood Ratio & 280,571 & 12 & ,000 \\
\hline $\begin{array}{l}\text { Linear-by-Linear } \\
\text { Association }\end{array}$ & 15,478 & 1 & ,000 \\
\hline $\mathrm{N}$ of Valid Cases & 265 & & \\
\hline
\end{tabular}

a. 12 cells $(60,0 \%)$ have expected count less than 5 . The minimum expected count is, 18 . 
These results also report that there is statistically significant relationship between the variables for Elibrary (chi-square with 12 degree of freedom $=436,276, \mathrm{p}<0.05$ ) and thus Null hypothesis $\mathrm{H}_{2 \mathrm{~d}}$ is rejected implying that alternative hypothesis $\mathrm{H}_{2 \mathrm{~d}}$ is supported.

Internet $\left(\mathrm{H}_{2 \mathrm{e}}\right)$

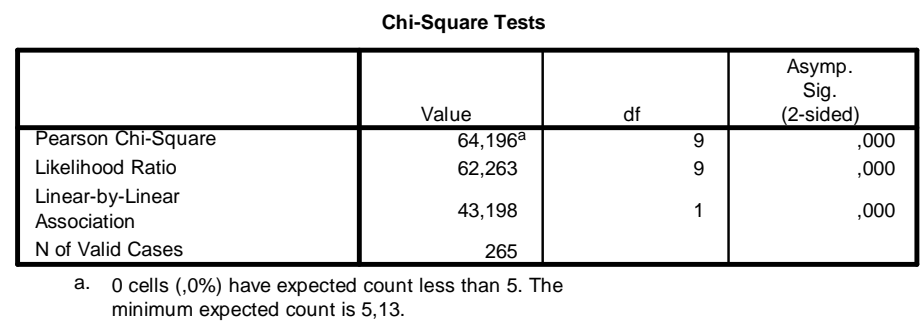

These results show that there is statistically significant relationship between the variables for internet (chi-square with 9 degree of freedom $=64,196, p<0.05$ ) and thus Null hypothesis $\mathrm{H}_{2 \mathrm{e}}$ is rejected implying that alternative hypothesis $\mathrm{H}_{2 \mathrm{e}}$ is supported.

Internet Electronic Bulletin Board $\left(\mathrm{H}_{2 \mathrm{f}}\right)$

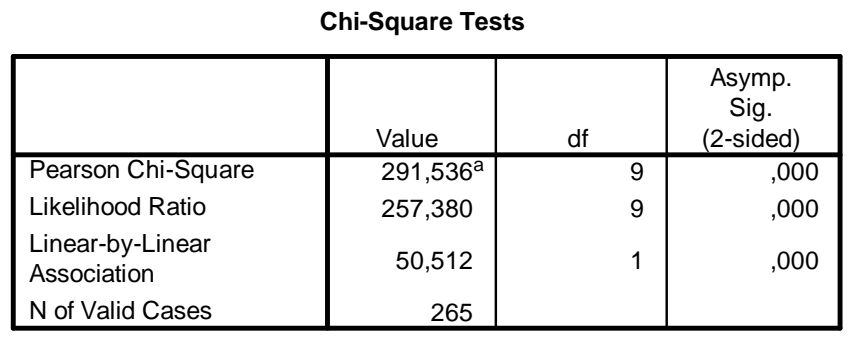

a. 3 cells $(18,8 \%)$ have expected count less than 5 . The minimum expected count is 2,44

These results indicate that there is a statistically significant relationship between the variables for Internet electronic bulletin board (chi-square with 9 degree of freedom $=291,536, p<0.05$ ) and thus Null hypothesis $\mathrm{H}_{2 \mathrm{f}}$ is rejected implying that alternative hypothesis $\mathrm{H}_{2 \mathrm{f}}$ is supported.

Table 1.5: Summary of the Results of the Testing of Hypothesis 2

\begin{tabular}{|l|l|}
\hline$H_{2 a}$-Companys Website & Supported \\
\hline$H_{2 b}$-E-mail & Supported \\
\hline$H_{2 c}$-Video Conferencing & Supported \\
\hline$H_{2 d}$-E-library & Supported \\
\hline$H_{2 e}$-Internet & Supported \\
\hline$H_{2 f}$ - Internal Electronics Bulletin Board & Supported \\
\hline
\end{tabular}

Finding for Hypothesis 2

The above six sub-hypotheses are supported by the views indicated by the employees in the Turkish SMEs and overall $\mathrm{H}_{2}$ is thus accepted. 
Finally, the results show that hypothesis $\mathrm{H}_{1}$ is not accepted because the respondents did not think that ideas obtained from buyers and suppliers can be used to enhance the knowledge transfer in SMEs. Finally various IT resources are considered in line with the available literature to find the effect of these for KT in Turkish SMEs. The analysis results show that some of the known IT technologies in Turkey such as E-mail, Internet, website etc. are also considered valuable and the related hypothesis $\mathrm{H}_{2}$ is also accepted. This shows the general trend of considering various themes affecting the development of KT in Turkish textile and apparel industry.

Limitations of the Study:

This study provides an insight into the Turkish textile and apparel industry and establishes the qualitative and quantitative approach to find out the important determinants for knowledge transfer activities. The study was conducted using standard procedures. A number of limitations, however, are noted for this study:

- Textile and apparel industry is one of the biggest manufacturing industries in Turkey and data collected for analysis were from only 265 respondents. The response might not thus truly act as representative of the whole Turkey and the findings may not be generalized at large.

- The study was conducted only in the four big cities (Istanbul, Ankara, Bursa and Izmir) but textile and apparel industry in Turkey is widespread in small towns and villages and may represent different views for KT.

- One of the limitations of this research is the complexity of the terms used for knowledge transfer in Turkish textile and apparel industries and was narrowed down sometimes for the purpose of the study.

Further Recommendations:

- A number of recommendations, which follow from this initial study, are made below for future research:

- This study can be extended to study the knowledge transfer activities in any SMEs discipline.

- A larger study might be conducted by adding the parameter to study the knowledge transfer mechanism in any big enterprise.

- This study can be used to make a comparison of knowledge transfer activities in SMEs either in the same country or several developing countries.

\section{CONCLUSION}

Accepting knowledge transfer activities in a broader perspective is both beneficial and important because it provides a set of tools and a visualization that allows better understanding and certain interventions if needed. Elements including knowledge sharing and IT technology played a big role in this study in discovering the knowledge transfer practices in Turkish SMEs.

A vast majority of the Turkish textile and apparel industry runs as a family business and they mostly rely on old technology and also are reluctant to change. Owners or managers do not consider that KT is important for the success of their business and want to prevent outflow of knowledge from the company. This also puts barriers in acquiring knowledge from outside, and makes knowledge trans- 
fer activities even harder. This study proposed four themes necessary for the success of KT and illustrated the important practices used to achieve effective knowledge transfer in Turkish textile and apparel industry. Although many factors considered in literature reviews were found not important in the context of Turkish textile and apparel industry but are sufficient at present to influence the other textile and apparel industries to start the knowledge transfer activities in their organization. They require to shed their conservative approach and to adopt best practices from all over the world to survive in today's rapidly evolving global market with intense competition. Therefore, the textile and apparel industry in Turkey adapt to practices the knowledge transfer activities and this will both help and enforce them to improve continuously. The results point to knowledge transfer in a firm to be crucial for subsequent actions in the Turkish market. Another implication for managers is that the customer is connected to other business therefore supplier has to understand what happens in the business exchange for knowledge sharing activities. 


\section{REFERENCES}

Akalin, M. (2001), Insight into the Turkish Textile and Apparel Industry, Electronic Journal of Textiles, Vol 1, No 1, 25 (1), pp: 107- 133.

Argote, L., and Ingram, P., (2000), Knowledge transfer: A Basis for Competitive Advantage in Firms, Organisational Behavior and Human Decision Processes, 82 (1), pp: 150- 169.

Argyris, C., and Schon, D.A., (1974), Theories of Action in Practice - Increasing Professional Effectiveness. Jossey- Bass, San Francisco.

Argyris, C., and Schon, D.A., (1978), Organizational Learning: A Theory Action Perspective. Addison-Wesley, Reading MA.

Bajracharya, P., Masdeu, N.R., (2006), Tacit Knowledge Transfer, In Small Segment of Small Enterprises, International Master's Program in Strategy \& Culture LIU- EKI/STR- D- 06/003- SE, Linköping University, Sweden.

Boisot, M., (1998), Knowledge Assets: Securing Competitive Advantage in the Information Economy, Oxford University Press, New York.

Davenport, T.H., and Prusak, L., (1998), Working Knowledge: How Organizations Manage What They Know, Harvard Business School Press, Boston, MA.

Davenport, T.H., and Prusak, L., (2000), Working Knowledge. How Organizations Manage What They Know. Harvard Business School Press, Boston.

Demarest M., (1997), Understanding Knowledge Management, Long Range Planning, 30 (3), pp: 374- 384.

Eraslan, İ.H., (2008), The Effects of Competitive Strategies on Firm Performance: A Study in Turkish Textile and Apparel Industry Considering Mediating Role of Value Chain Activities, Unpublished PhD Dissertation, Boðaziçi University.

Ercan E., (2002), Changing World Trade Conditions Force the Turkish Textile and Apparel Industry to Create New Strategies, Journal of Textile and Apparel, Technology and Management, Vol 2, Issue IV, Fall.

Export Promotion Center (ÝGEME) (2008), Annual Reports and Statistical Data, T.C. Bapbakanlýk Ýhracatý Geliptirme Etüd Merkezi (ÝGEME), retrieved from http://www.igeme.org.tr.

Frappaolo, C., and Capshaw, S., (1999), Knowledge Management Software: Capturing the Essence of Know-how and Innovation, The Information Management Journal, July, pp: 44- 48.

Garvin D.A., (1993), Building a Learning Organization, Harvard Business Review, July/ August, pp: 78-91.

Grant, R.M., (1996), Prospering in Dynamically Competitive Environments: Organizational Capability as knowledge integration, Organization Science, 7 (4), pp: 175- 387.

Gutpa A.K. \& Govindarajan V., (2000a), Knowledge Flows Within Multinational Corporations, Strategic Management Journal, 21, pp: 473- 496. 
Gynawali, R., Stewert, H., and Grant, H., (1997), Creation and Utilization of Organizational Knowl-edge: An Empirical Study of the Role of Organizational Learning on Strategic Decision Making, Academy of Management Proceedings, pp: 16- 20.

http://www.kosgeb.gov.tr/Ekler/Dosyalar/Information/6/Sme.doc

Huber, G., (1991), Organizational Learning: The Contributing Processes and the Literatures, Organi-zation Science, 2 (1), pp: 88- 115.

Huysman, M., and DeWit, D., (2002), Knowledge Sharing in Practice, Kluwer Academics, Dordrecht.

Levitt, B., and March, J.G., (1988), Organizational learning, Annual Review of Sociology, 14, pp: 319-340.

March, J.G., and Olsen, J.P., (1975), The Uncertainty of the Past: Organizational Learning under Ambiguity, European Journal of Political Research, 3, pp: 147- 171.

McAdam, R., and McCreedy, S., (1999), The Process of Knowledge Management within Organizations: A Critical Assessment of Theory and Practice, Knowledge and Process Management, 6 (2), pp: 101- 113.

Nonaka, I., (1991), The Knowledge Creating Company, Harvard Business Review, 69, pp: 96- 104.

Nonaka, I., and Takeuchi, H., (1995), The Knowledge Creating Company, Oxford Press, Oxford.

Polanyi, M. (1967), The Tacit Dimension. Anchor, Garden City, NY.

SPSS http: // www. psychstat. missouristat.edu

Stewart T.A. (2001), Intellectual Capital: Ten Years Later, How Far We've Come, Fortune, May 28, pp: $1-3$.

Stewart, T., (1997), Intellectual Capital: The New Wealth of Organizations, Currency

Doubleday, New York, NY.

Stover, M., (2004), Making Tacit Knowledge Explicit, Reference Services Review, Vol 32, No 2, pp: 164- 73.

Swan J., Newell S., Scarbrough, H., and Hislop, D., (1999), Knowledge Management and Innova-tion: Networks and Networking, Journal of Knowledge Management, 3 (4), pp: 262- 275.

The General Secreteriat of Istanbul Textile and Apparel Exporter Associations (ITKIB), 2006. Aannual Reports and Statistical Data, Retrieved from, http: //www.itkib.org.tr

Turkish Clothing Manufacturers Association (TCMA) (2008), Annual Reports and Statistical Data, Türkiye Giyim Sanayicileri Derneði (TGSD), Retrieved from http://www.tgsd.org.tr Yang, G., (2003), The Internet and Civil Society in China: A Preliminary Assessment, Journal of Contemporary China, Vol 12, No 36, pp: 453- 475. 